\title{
Affirmatives in Early Modern English
}

\author{
Yes, yea and ay
}

Jonathan Culpeper

Lancaster University

This study examines the affirmatives yes, yea and ay in Early Modern English, more specifically in the period 1560 to 1760 . Affirmatives have an obvious role as responses to yes/no questions in dialogues, and so this study demanded the kind of dialogical material provided by the Corpus of English Dialogues 1560-1760. I examine the meanings and contexts of usage of each affirmative: their distribution across time and text-types, their collocates and their occurrence after positive and negative questions. The results challenge a number of issues and claims in the literature, including when the "Germanic pattern" (involving yes and yea after positive or negative questions) dissolved, whether yea or ay were dialectal, and the timing of the rise of ay and the fall of yea.

Keywords: affirmatives, ay, Early Modern English, response forms, yea, yes

\section{Introduction}

In present-day English, the item yes is considered to be a "response form", and is strongly associated with yes/no questions (Biber et al. 1999:1089-1090). Historically, this was broadly true for earlier stages of the English language (e.g., Wallage and van der Wurff 2013). Its exploration therefore requires dialogical material. $A$ Corpus of English Dialogues 1560-1760 (CED) offers an ideal and unique opportunity to establish its usage in the latter part of the early modern period. Then, yes was jostling for pragmatic space with two other forms: yea, a form that dates from the earliest stages of English, and ay, a form that, according to the Oxford English Dictionary, first appeared in the late-sixteenth century. An important pattern of usage to consider - the so-called "Germanic pattern" - is one that was well-established in Old English (OE), namely, that yea was used as a positive response to positive questions, whereas yes was used as a positive response to negative ones. 
Was this pattern evident in Early Modern English (EModE)? This paper will reveal the meanings, linguistic patterns of usage and contexts of EModE affirmatives.

\section{Background to English affirmatives: Yes, yea and ay}

\subsection{Etymological background}

There were two central affirmative forms meaning 'yes' in OE. One was gea (i.e., $y e a)$, derived from Proto-Germanic ${ }^{\star} j a$. This, of course, is the translation equivalent of English yes in many Germanic languages today. The other form was gyse, which evolved into the yes of today. Virtually all accounts agree that yes was formed from gea plus some other element(s). What is controversial, though, is what other element(s) is/are involved. There are three proposals. A summary of these based on Wallage and van der Wurff (2013) is given below.

1. The oldest proposal, put forward by the early English etymological pioneers such as Partridge, Skeat and Wyld, is that OE gyse is a coalesced form of gea swa, where swa has the sense of 'so'. Thus, gea swa means 'yea, (it is) so'. This seems to parallel Romance si and its derivation from Latin sic est. However, there are clear problems, as noted by Wallage and van der Wurff (2013:193-195). One is that swa is not used on its own in OE to signal affirmation, which is frequently the case with gyse. Another is that swa does not predominantly occur in clause-initial position, unlike gyse. And finally, the phonology does not work. Attested forms of gyse (i.e., gese, gyse, gys, gise and ise) suggest a vowel affected by the conditions of $i$-mutation. But swa does not contain those conditions: it has no /i/ or / $\mathrm{j} /$.

2. The Oxford English Dictionary suggests the following explanation in its entry for yes: OE gyse is taken to be a coalesced form of gea sie, where sie is the third-person singular present-tense subjunctive of beon ('to be'). It has the sense of 'yea, be it,' 'yea, let it be!', and so on. The possible phonological development into yes is seductively easy to see. However, there are problems with this account, as Wallage and van der Wurff (2013:196-197) observe. Firstly, it is strange to have a subjunctive in an affirmative reply. Secondly, it captures a very narrow slice of the meanings expressed by $\mathrm{OE}$ gyse. It fits cases where someone endorses an utterance asking about a course of action or state of affairs, but not the many other cases affirming an opinion that has been expressed (which would be incompatible with third person sie) or a past or future state of affairs. Thirdly, there is very little evidence that sie was normally used as (part of) a response to a yes/no question - a key contextual environment throughout the history of yes. 
3. The final proposal comes from Wallage and van der Wurff (2013). Their idea is that OE gyse derives from gea (hit) is swa, which has the sense of 'yea, (it) is so. Crucial to this proposal is the argument that hit could be left unexpressed. Wallage and van der Wurff (2013:200-202) cite evidence that referential subjects could remain unexpressed, especially when the antecedent is in the preceding clause - the very context of gea (hit) is swa used as a response item. ${ }^{1}$ With the reduction to gea is swa, regular phonological processes produce the form gyse. Syntactically, it originates as a short clause preceded by a polarity marker, and then routinizes and coalesces (univerbates) into gyse. Pragmatically, this account also helps to explain why gyse for many years tended to occur after negative questions. Gea (hit) is swa resolves the pragmatic ambiguity inherent in negative questions by confirming the implied belief that something is the case and blocking the copying of the literal proposition. I will illustrate and elaborate on this post-question pattern in the next section.

The etymology of ay should also be mentioned. Ay seems to have received, at best, passing treatment from scholars. The Oxford English Dictionary (OED Online) suggests the following in the entry for "aye | ay, int. (and $a d v$.) and n.":

Appears suddenly about 1575 , and is exceedingly common about 1600 ; origin unknown. The suggestion that it is the same as AY adv. 'ever, always', seems set aside by the fact that it was at first always written $I$, a spelling never found with AY $a d v$. But it may have been a dialect form of that word, from some dialect in which it had passed through the senses of always, in all cases, to by all means, certainly, yes (compare aye but, in sense A. $2 \mathrm{~b}$; and the history of ALGATE $a d v$.), and so have been taken in literary English for a different word.

Some of these claims about ay will be examined in our analyses.

\subsection{Responses to questions: Yes and yea and the Germanic pattern}

To raise pertinent historical issues, let us start with a present-day example, reconstructed from memory (the key feature(s) in examples are in boldface):

(1) Emily: Didn't you take my costume out of the washing machine? Jonathan: Yes.

Emily: What?

1. The idea that $\mathrm{OE}$ could have options for null subjects is a key part of this proposal. Wallage and Van der Wurff (2013) cite Walkden (2013), but other research has supported the idea. See, for example, van Gelderen (2013) and Rusten (2013). 
Jonathan's response is unhelpful because of its ambiguity. There are two possible meanings:

Meaning 1: Yes, what you say is true, I didn't take your costume out of the washing machine. (Confirms the negative proposition in the question. Note that the meaning "copies" what was said in the question, albeit with appropriate deictic adjustment.)

Meaning 2: Yes, what you suppose is true, I did take your costume out of the washing machine. (Confirms the positive proposition generated as an implicature in context.)

This situation would not have arisen in OE. At that time, according to Wallage and van der Wurff (2013:191), a clear generalization about usage is possible:

a. to give positive-polarity response to a positive utterance, use gea;

b. to give positive-polarity response to a negative utterance, use gyse

Henceforth, this pattern of usage will be referred to as the "Germanic pattern". Thinking about Example (1), it is most likely that Jonathan, had he been transported back in time, would have replied with gyse, given that a negative question had been asked. In doing so, he would have achieved a positive-polarity response, or, in other words, the second meaning confirming the implicature that he did take the costume out of the washing machine. Unlike gea, gyse targets the implicature. The reason it does this relates to the derivation from gea is swa, as argued by Wallage and van der Wurff (2013) (see Section 2.1). Gea alone allows the affirmation of the proposition copied (and subsequently ellipted) from the question along with its negative polarity, in other words, "yes (I didn't take your costume out of the washing machine]". But gea followed by the full clause is swa (i.e., the suggested etymology of gyse) would block any simple copying operation (Wallage and van der Wurff 2013:208), leaving it unambiguously to target the implicature.

Wallage and van der Wurff (2013:208) also note that in present-day English blocking operations, such as that achieved by gea is swa, are more often carried out by spelling out the subject and auxiliary of the clause (e.g., "Didn't you take my costume out of the washing machine?" / "Yes, I did"). I will briefly return to such responses in the following section.

\subsection{The situation in EModE}

Aside from Wikberg's (1975) study of yes-no questions and answers in Shakespeare's plays, and Archer's (2005) study of questions and answers in the courtroom (the data for which is drawn from the CED), research on the questionanswer system is thin. Moreover, even those two studies have little to say 
specifically about the affirmatives yes, yea and ay. We are limited to a handful of papers, passing comments in related works, and dictionary or grammar entries. Nevertheless, a tentative descriptive picture does emerge, and one for which the details can be substantiated or refuted in the forthcoming analyses.

Wikberg $(1975: 208)$ generalizes as follows:

The overwhelming evidence indicates that most $\mathrm{Q}$ [uestion]/R[esponse]-patterns are structurally identical in Shakespeare's and Present-Day English, if in questions the criteria are finiteness, inversion, tags and dependence, and in answers sentence adverbials, expansion, repetition, and the various semantic relationships.

Vennemann (2009:331) offers a view about when the shift to the present-day system occurred:

the English answering system is a Late Middle English and Early Modern English innovation, consolidating in the two centuries between Chaucer (1343-1400) and Shakespeare (1564-1616).

The major difference between the $\mathrm{OE}$ answering system and today's is precisely the presence of the Germanic pattern of yes/yea usage, as discussed in Section 2.2. The question then is, when did it disappear?

The following statements summarize claims about affirmatives in EModE:

- The Germanic pattern can be detected in EModE (Salmon 1965:133).

- The Germanic pattern breaks down around 1600, with yes taking over all functions (Crystal and Crystal 2002:373)

- Yea is relegated to emphatic usage and regional dialect (Crystal and Crystal 2002:373)

- Ay "appears suddenly about 1575 , and is exceedingly common about 1600 ", and is "perhaps a dialect form" (OED).

- Ay comes to follow the same kind of usage patterns as yea (Salmon 1965:133)

- Ay encroaches on yes, maybe distorting its pattern of usage (Blake 2002:161)

Why might changes, particularly regarding the Germanic pattern, have taken place? Vennemann (2009) proposes that it might have been partly a consequence of contact with Insular Celtic. The background to this idea was very briefly mentioned at the end of the previous section - namely, that answers today often consist of spelling out the subject and auxiliary of the clause. Example (2) reworks Example (1) to illustrate the point.

(2) Emily: Didn't you take my costume out of the washing machine?

Jonathan: (Yes) I did / (No) I didn't.

Emily: Ok. 
As Vennemann (2009) notes, often the answer to a yes/no question in present-day English is not a simple yes or no, but yes or no along with a subject and auxiliary or modal verb, or even just the subject and auxiliary or modal verb. Vennemann (2009:310-313) compares responses to yes/no questions in the context of English and German wedding ceremonies. In English wedding ceremonies, questions such as "Will you have this man to be your husband?" receive I will, or "Do you take this man to be your husband?" receive $I$ do. The equivalent questions in German wedding ceremonies receive Ja. English, then, is prioritising what Filppula (1999) refers to as "modal only" types of response. This was not the case in OE. Where, then, does this modal response come from? Vennemann (2009) notes that Irish has no exact equivalent of yes or no, and that, similarly, Welsh favours modal only responses. His argument is that Anglo-Saxon contact with the Celtic language, Brythonic, resulted in this English habit of answering, a habit which worked its way up the social ladder into educated discourse between the time of Chaucer and Shakespeare. Vennemann's (2009) argument, of course, is part of the "Celtic Hypothesis", the idea that the Celtic languages had a significant effect on the development of English (Filppula and Klemola [eds] 2009; see also the overview in Hickey 2012). The relevant point for this article is that the neat Germanic answering system was possibly destabilized by Celtic influence.

\section{Spelling variants}

The first step in this study was to retrieve all variants for yes, yea and ay given in the Oxford English Dictionary (OED Online) for the period covered by the CED. These were pooled with various other plausible spelling variants (e.g., ye and $a$ ). Each variant was searched for in the CED using CQPweb. The results are given in Table 1.

Table 1. Yes, yea and ay: Spellings and frequencies

\begin{tabular}{llll}
\hline Lexeme & Yes & Yea & \multicolumn{1}{l}{$A y$} \\
\hline Spelling variants & None & None & Ay $(251)$ \\
& & & Aye $(17)$ \\
& & & $I(55)$ \\
Frequency & 1,368 & 289 & 323 \\
\hline
\end{tabular}

$I$ as a spelling variant of ay presented a search challenge, for the obvious reason that it has the same form as the first-person pronoun. However, a particular context of occurrence was identified: $I$ always occurs after a major syntactic division indicated by a punctuation mark, either a full-stop or colon, and is followed 
by a clause to which it is loosely related, the relationship being marked by a comma. Thus, retrieval of instances was made possible through the following regular expression: “( $\mid$. | $\mid$ : $) I \backslash$,. Henceforth, in this paper the variants ay, aye and I will be referred to collectively by AY in small capitals. ${ }^{2}$

Before leaving this section, we should recollect the argument made in the OED about the etymology of AY: "The suggestion that it is the same as AY $a d v$. 'ever, always,' seems set aside by the fact that it was at first always written $I$, a spelling never found with AY $a d v$.". It seems to be true that $a y(e)$ as an adverb meaning 'ever, always' was always written thus; I failed to find contrary evidence in either the CED or the broader Early English Books Online (EEBO-TCP). Still, the OED's argument is weak, since from the beginning AY as an affirmative could be written either $a y(e)$ or $I$. The earliest instances in the CED occur in John Lyly's Alexander, dating from 1584, where it is spelt both $I$ and ay. The implication of this is that there is nothing blocking its pragmatic development from the meaning of the adverb $a y(e)$ in a straightforward fashion through the strengthening of implicatures. In fact, the OED alludes to the possible path of development, passing "through the senses of always, in all cases, to by all means, certainly, yes" (OED).

\section{Global contexts: Time and text-types}

\subsection{Distribution over time}

Figure 1 displays the density of instances of yes, yea and AY in the CED over the period 1560 to 1760 . Figure 1 displays strikingly the dominance of yes, which steadily increases in density over the period 1560 to 1760 . There are two possible reasons for this. One is that the usage of yea was equally steadily declining, and yes increased in frequency to fill the space it left. This decline is consistent with the idea that yea was being "relegated to emphatic usage and regional dialect" (Crystal and Crystal 2002:373), though later we will scrutinise the specific claims about emphatic usage and regional dialect. The other is that the increase in yes was being driven by a general change in dialogical genres of the type included in the CED - they were becoming more colloquial and dialogical (e.g., Culpeper and Kytö 200o). This factor would in principle affect all affirmatives. But as we see, that is not evident with yea. Still, it is entirely plausible that the massive reduction in yea could not be off-set by a general increase in affirmatives.

2. One other spelling variant was found, namely, ye. This was excluded from the study because of uncertainty about what it represents and its provenance. 


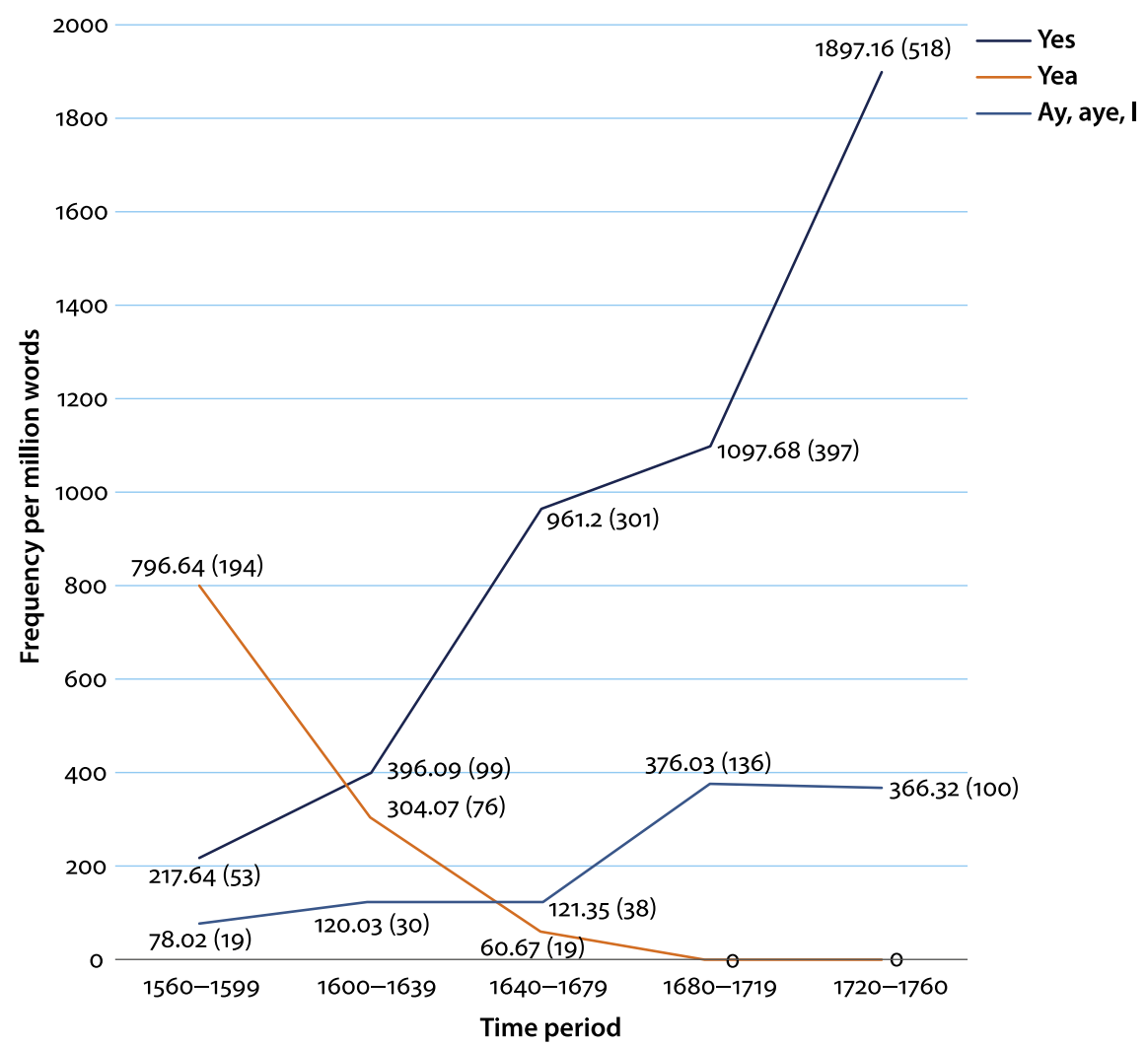

Figure 1. Distribution of yes, yea and AY from 1560 to 1760 in the CED (frequency per million words; raw frequencies are in parentheses)

AY does not appear to follow the development of yea, despite Salmon's (1965:133) claim that it does. Instead, it exhibits an increase in density of occurrence, especially from the mid-seventeenth century onwards, albeit with an indication that it may have reached a plateau in the eighteenth century. This increase would be consistent with Blake's (2002:161) claim that ay encroaches on yes. However, the distribution of combined $\mathrm{AY}$ is not consistent with the OED's claim that it "appears suddenly about 1575, and is exceedingly common about 1600". Figure 1 suggests that it was least common around 1600, expanding thereafter. One possible explanation is that the OED editors merely formed an impression of the word's commonality around 1600 , and this was driven by the salience of one of its variants, namely, $I$. Furthermore, it is worth bearing in mind that although the OED might be said to be based on a corpus of quotations, "it would be a mistake to regard them as a reasonably balanced representation of the English language" (Hoffmann 2004:21). Figure 2 displays the density of instances of $I$ in the CED over the period 1560 to 1760 . 


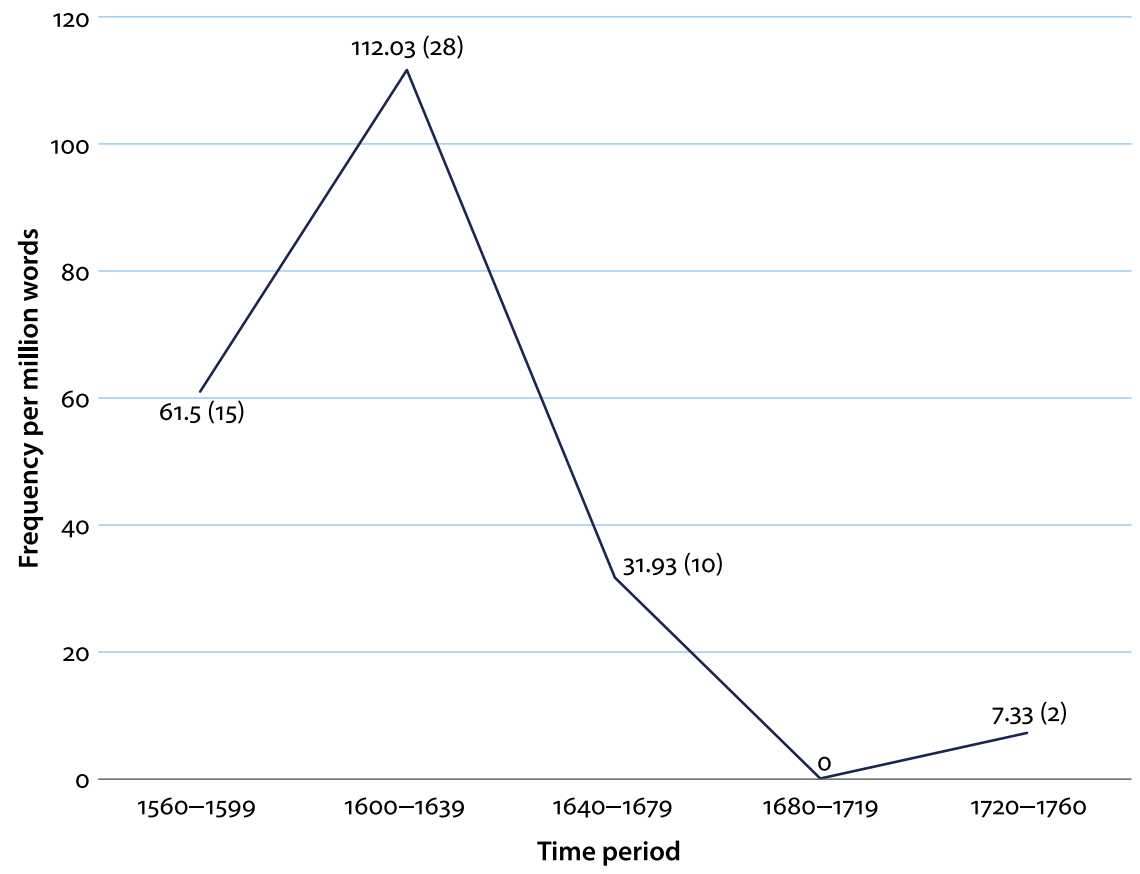

Figure 2. Distribution of affirmative $I$ from 1560 to 1760 in the CED (frequency per million words; raw frequencies are in parentheses)

As Figure 2 shows, affirmative $I$ does indeed have its heyday around 1600. As a spelling variant, it should be noted that it was not particularly frequent, which is why its frequency early in the seventeenth century does not reveal itself in the combined results for ay, aye and $I$ in Figure 1. The salience of this variant is probably due to three facts. One is that it reaches its peak in frequency very shortly after it originated; in other words, it made a relatively dramatic entry. The OED claims that it appears about 1575 . No occurrences in the CED appear before that date. Another is that for the first two periods it is the dominant AY variant. For example, twenty-eight of the total thirty AY variants for 1600 to 1639 are $I$. The final fact is that the variant was used with particular frequency in Shakespeare's First Folio, with all the prestige and fame that that volume brings with it. As Hoffmann (2004: 21) notes, "Shakespeare's works contribute almost 33,000 quotations to the first edition of the $O E D$ ", and the largest body of Shakespeare's works used by the OED team was the First Folio. $I$ is used 302 times in the First Folio with a relative frequency of 278.92 . That is highly dense, especially when one compares with the highest numbers for a period in the CED: the second period (1600 to 1639), where it occurs twenty-eight times with a relative frequency of 112.03. Perhaps one explanation for its usage was that it took little space. If a compositor, as often happened 
in the First Folio, found that his calculations for laying out the text across a certain number of leaves of paper turned out to be slightly incorrect, there may well have been a strong need to save space (see Blayney 1991, for further detail on the First Folio and its construction).

\subsection{Distribution over text-type}

Figure 3 displays the density of instances of yes, yea and AY in the various texttypes of the CED.

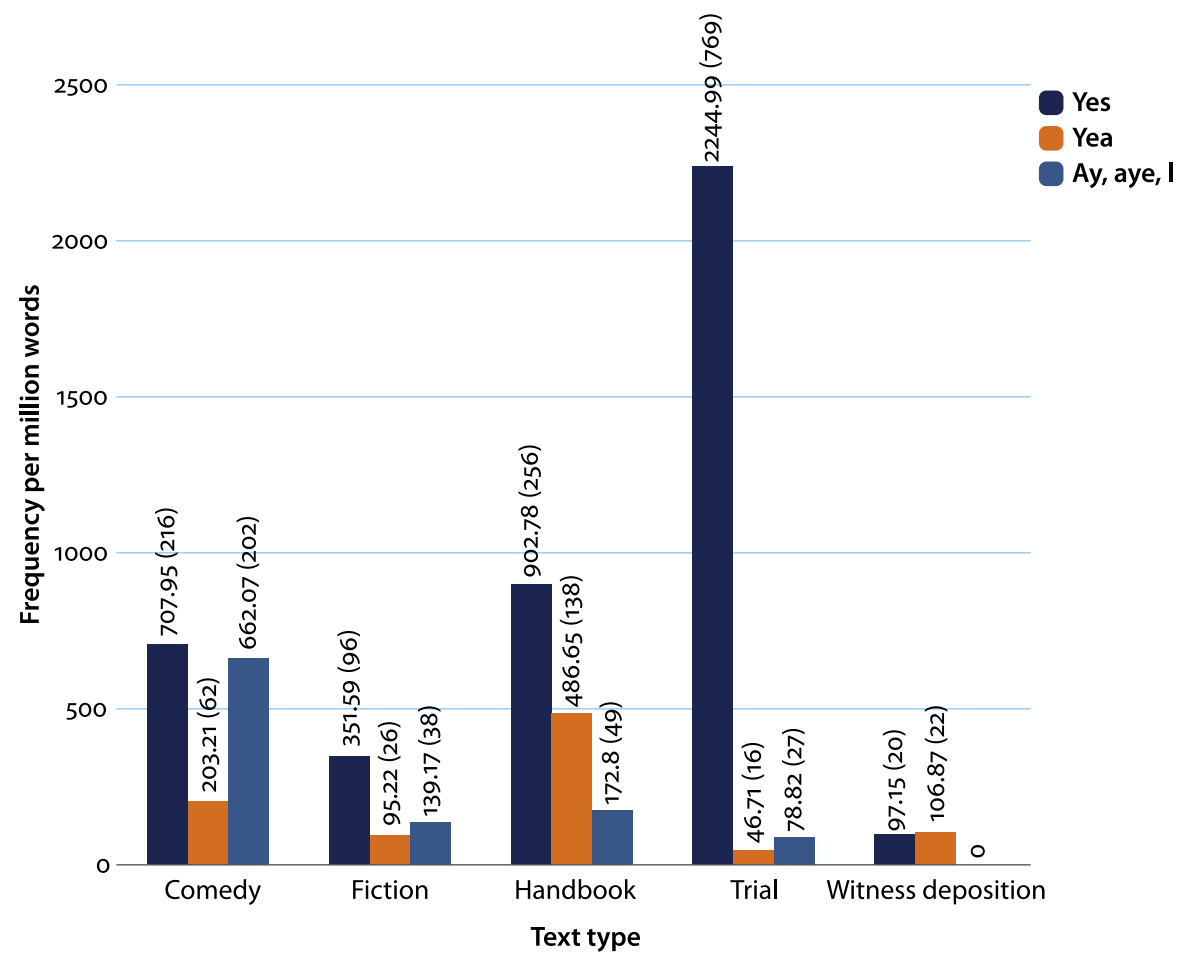

Figure 3. Distribution of yes, yea and AY in the text-types of the CED (frequency per million words; raw frequencies are in parentheses)

All affirmative types are represented in all text-types, except in witness depositions, where the AY group does not occur. Nothing can be concluded from this particular absence, because, generally, witness depositions attract only few affirmatives. This is not surprising, since witness depositions are third-person narratives, often witness statements, and are thus less amenable to the dialogical exchanges where affirmatives thrive. Prose fiction is constituted by third-person 
narration, and likewise affirmatives are rare here, though they occur somewhat more frequently than in witness depositions - probably because prose fiction sometimes deploys direct speech report to animate and dramatise character interaction. All instances of affirmatives in prose fiction occur in the context of direct speech report, typically following a yes/no question where they initiate a response, as illustrated in Example (3).

(3) But heare you Gossip, shall I bee so bold to aske you one question more? Yes, withall my heart quoth shee. I heard say that your husband would now put you in your hood, and silke gowne, I pray you is it true? Yes in truth, quoth mistresse Winchcomb [...]

Thomas Delony (1619) The Pleasant History of Iohn Winchcomb [...]

Trial proceedings are striking for the density with which yes occurs. In large part this is due to the question-answer sequences constituting cross-examination, as in Example (4).

(4) Question. Do you know the Prisoner at the Bar?

Answer. Yes.

Q. Did you know the deceased Mr. Francis Elcock?
A. Yes.
The Tryal (at large) of John Stevenson [...], 1759

The remaining genres, comedies and handbooks, although dominated by yes, contain reasonable quantities of the other variants. The presence of these quantities of affirmatives in comedies is not surprising, given the dialogical nature of the text-type. Culpeper and Kytö (2000:186), examining the occurrence of interactive linguistic features in the text-types of the CED, concluded that "there is a strong case for claiming drama to be closest to 'real' spoken interaction". Drama comedy is the only text-type in which AY appears with any frequency, something which perhaps hints at its colloquial flavour. It is quite striking, however, that the AY group is only just behind yes. This is consistent with Blake's (2002:161) remark that ay encroaches on yes. Incidentally, there is no evidence in any of the texttypes that the AY variants are socially restricted or considered to be a marker of regional dialect. They are used by characters or people of varying ranks, and in formal contexts as well as informal ones. This contradicts the OED's suggestion that ay might have developed as a dialectal form.

Turning to handbooks, the reason for the fairly dense occurrence of affirmatives is likely to be the scholastic model for didactic instruction: the use of question-and-answer sequences between a notional teacher and pupil, by means of which others can learn (see Culpeper and Kytö 2010:42, for discussion of this model). What is surprising is the distinctively high density with which yea occurs, and especially in English language teaching (ELT) texts. In ELT texts, yea occurs 
with a density of 773.40 (per million words), whereas for other didactic works it is 349.38. Almost all of these ELT texts were written for the instruction of French refugees and immigrants. Recollect that yea is the variant Crystal and Crystal (2002:373) claim to be "relegated to emphatic usage and regional dialect" in Shakespeare's time. It seems highly unlikely that ELT books would select a regional dialect variant for their learners to emulate. This may be evidence that yea was not considered to be dialectal at the time. However, evidence from the CED covers a 200-year period, whilst Crystal and Crystal's statement pertains to Shakespeare's period (very approximately a decade either side of 1600). Consequently, we need to ascertain whether the ELT data relate to the two CED periods, 1560 to 1599 and 1600 to 1639 , which overlap with Shakespeare. Of the total of seventy-one instances in the entire CED, forty-three occur in the period 1560 to 1599 , and the remaining twenty-eight occur in the following period, 1600 to 1639. Whilst some caution is necessary when interpreting these figures, as the material for handbooks is not evenly dispersed over time, the conclusion is still valid: ELT books from Shakespeare's time were using yea as the model for their learners. One might argue that the authors of these books were generally not native speakers of English. Even so, minimally, one can still conclude that yea was not well-known as a regional dialectal variant. Part of the problem in discussing all this concerns what exactly is meant by "regional dialect". It is plausible that yea reflects the dialect not of a region as such but of middle-ranking city dwellers. These handbooks have dialogues set in London, and are populated by broadly middle-ranking folk, from schoolteachers to pub landlords. Furthermore, this is perfectly in tune with their readership. They were not pitched at the nobility or the lower ranks, but the middle-ranking immigrants who had to make their way in the city.

\subsection{Local contexts: Collocations and preceding questions}

\subsubsection{The collocations of yes, yea and $A Y$}

Using CQPweb, I identified the collocates of yes, yea and AY. I searched only within the text-type of comedy plays, partly because they contain good numbers of all three items (see Figure 3), but also because it is a text-type that is not restricted to a formalised speech event, as one might get in a trial proceeding. The statistic used was Dice coefficient, "a measure whose results reflect a combination of significance (amount of evidence) and effect size (strength of connection), producing a compromise ranking relative to single statistics" (CQPweb note). To discourage localised results, I set the minimum frequency of both the target item and its collocate at ten. The results are reported in Tables 2 to 7 . Results are 
ordered according to the Dice coefficient value; only the top five are given. ${ }^{3}$ There are two tables for each of the three target items, one concerning collocates to the left of the item within a 5-word window, and one concerning collocates to the right within a 5-word window. For each collocate in the tables, I include a brief example. Due to space constraints, original lineation is not followed; run-on is used instead. To enhance legibility, I have italicised character labels, and emboldened the example collocate.

Tables 2 and 3 display the collocates for yes.

Table 2. Collocates within a 5-word window to the left of yes in the CED Comedies

\begin{tabular}{|c|c|c|c|c|c|c|}
\hline Word & $\begin{array}{l}\text { Total no. } \\
\text { in CED } \\
\text { Comedies }\end{array}$ & $\begin{array}{l}\text { Expected } \\
\text { collocate } \\
\text { frequency }\end{array}$ & $\begin{array}{l}\text { Observed } \\
\text { collocate } \\
\text { frequency }\end{array}$ & $\begin{array}{l}\text { In } \\
\text { no. } \\
\text { of } \\
\text { texts }\end{array}$ & $\begin{array}{l}\text { Dice } \\
\text { coefficient } \\
\text { value }\end{array}$ & Brief examples \\
\hline yes & 216 & 0.765 & 16 & 10 & 0.074 & $\begin{array}{l}\text { Is it you? Frank. Yes! yes! } \\
\text { (D5CHOADL) }\end{array}$ \\
\hline$?$ & 3,071 & 10.87 & 97 & 21 & 0.059 & $\begin{array}{l}\text { Have you no more to say? Bel. } \\
\text { Yes, I say you are the } \\
\text { beautifull'st of Women } \\
\text { (D) }{ }_{3} \text { CBROME) }\end{array}$ \\
\hline$O$ & 489 & 1.731 & 11 & 9 & 0.031 & $\begin{array}{l}\text { I hope you have made much } \\
\text { of him? Arch. O yes, Madam } \\
{[\ldots] \text { (D4CFARQU) }}\end{array}$ \\
\hline . & 22,129 & 78.325 & 287 & 24 & 0.026 & $\begin{array}{l}\text { Shall I expect you? Ful. Yes } \\
\text { with all my heart. } \\
\text { (D2CHEYWO) }\end{array}$ \\
\hline$!$ & 1,484 & 5.253 & 20 & 6 & 0.023 & $\begin{array}{l}\text { Sir Cred. In my Lungs! Prim. } \\
\text { Yes; where's your Pain? } \\
\text { (D5CMILLE) }\end{array}$ \\
\hline
\end{tabular}

Both Tables 2 and 3 have the same collocate in top position: yes. This simply reflects the fact that yes has a tendency to reduplicate, something which is typically, as the example illustrates, accompanied by exclamation marks, and expresses an effusive affirmative response. This effusiveness is also apparent in the fact that $O$ in Table 2 is also a collocate, partly acting to strengthen yes, but also perhaps lending a note of satisfaction. In Table 2, punctuation marks appear as collocates. The question mark and exclamation mark indicate a major preceding syntactic break, reflecting the fact that yes typically occurs at the beginning of a new conversational turn. The appearance of a full-stop as a collocate is not of much interest,

3. There is no gold standard for a "good" or "bad" Dice coefficient value, thus rank-ordering the results makes sense. Also, there can be no expectation that the Dice coefficient values across the tables will be similar, as the raw frequencies relating to the different variants differ. 
Table 3. Collocates within a 5-word window to the right of yes in the CED Comedies

\begin{tabular}{|c|c|c|c|c|c|c|}
\hline Word & $\begin{array}{l}\text { Total no. } \\
\text { in CED } \\
\text { Comedies }\end{array}$ & $\begin{array}{l}\text { Expected } \\
\text { collocate } \\
\text { frequency }\end{array}$ & $\begin{array}{l}\text { Observed } \\
\text { collocate } \\
\text { frequency }\end{array}$ & $\begin{array}{l}\text { In } \\
\text { no. } \\
\text { of } \\
\text { texts }\end{array}$ & $\begin{array}{l}\text { Dice } \\
\text { coefficient } \\
\text { value }\end{array}$ & Brief examples \\
\hline yes & 216 & 0.765 & 16 & 10 & 0.074 & $\begin{array}{l}\text { Is it you? Frank. Yes! yes! } \\
\text { (D) }{ }_{5} \text { HOADL) }\end{array}$ \\
\hline Madam & 475 & 1.681 & 18 & 8 & 0.052 & $\begin{array}{l}\text { I hope you have consider'd } \\
\text { the matter. Tar. Yes, Madam } \\
{[\ldots] \text { (D5CSTEEL) }}\end{array}$ \\
\hline sir & 1,892 & 6.697 & 39 & 12 & 0.037 & $\begin{array}{l}\text { Have they a woman? Das. } \\
\text { Yes sir, [...] (D2CBARRE) }\end{array}$ \\
\hline , & 24,184 & 85.599 & 220 & 24 & 0.018 & $\begin{array}{l}\text { Had yes neuer a brother? } \\
\text { Men.Cit. Yes, as I } \\
\text { remember, }[\ldots] \\
\text { (DiCWARNE) }\end{array}$ \\
\hline ; & 2,281 & 8.074 & 22 & 8 & 0.018 & $\begin{array}{l}\text { Does your Ladyship Love } \\
\text { me Madam? Const. Yes, yes; } \\
\text { I love to see you beaten. }\end{array}$ \\
\hline
\end{tabular}

because it simply reflects the preceding abbreviated character label, though, of course, it too indicates the turn initial positioning of yes. Regarding Table 3, both Madam and Sir suggest a politeness routine associated with giving responses. More specifically, these collocates are frequently used by servants and characters of lower ranks talking to those of higher ranks. The comma and semi-colon provide evidence of the fact that yes tends to have a loose association with the following material, as the examples illustrate.

Tables 4 and 5 display the collocates for yea. The collocates to the left, as displayed in Table 4, contain two punctuation marks that also appear in Table 2, the parallel table for yes: the question mark and the full-stop. Like yes, yea often appears at the beginning of a turn, where it acts as an affirmative response to the previous utterance. However, the presence of two other punctuation marks, the colon and the comma, suggest that it has some usages that are unlike yes. As the examples for those punctuation marks illustrate, it often occurs mid-turn. Here, one of yea's functions, as clearly illustrated in the example for the comma, is to act as a qualifier, adding extra information to develop a more precise version of something that has just been said. Table 5, which shows collocates to the right of yea, exhibits some similarities with the parallel table for yes (namely, Table 3). There we also find a comma as a collocate. The other punctuation mark here in Table 5, the full-stop, does not appear in Table 3 for yes, but there is some overlap with the semi-colon that one finds there, remembering, of course, that the notion of a sentence was not as clearly defined as it is today, and the semi-colon played 
Table 4. Collocates within a 5-word window to the left of yea in the CED Comedies*

\begin{tabular}{|c|c|c|c|c|c|c|}
\hline Word & $\begin{array}{l}\text { Total no. } \\
\text { in CED } \\
\text { Comedies }\end{array}$ & $\begin{array}{l}\text { Expected } \\
\text { collocate } \\
\text { frequency }\end{array}$ & $\begin{array}{l}\text { Observed } \\
\text { collocate } \\
\text { frequency }\end{array}$ & $\begin{array}{l}\text { In } \\
\text { no. } \\
\text { of } \\
\text { texts }\end{array}$ & $\begin{array}{l}\text { Dice } \\
\text { coefficient } \\
\text { value }\end{array}$ & Brief examples \\
\hline$?$ & 3,071 & 3.12 & 25 & 3 & 0.016 & $\begin{array}{l}\text { Count. What, will you go? } \\
\text { Mor. Yea sweet bird, I have } \\
\text { promised so. (D1CCHAPM) }\end{array}$ \\
\hline$:$ & 2,349 & 2.387 & 12 & 6 & 0.01 & $\begin{array}{l}\text { Men. She is gone: yea Apollo I } \\
\text { will sacrifice this olde beast } \\
\text { vnto thee ((D1CWARNE) }\end{array}$ \\
\hline . & 22,129 & 22.482 & 63 & 4 & 0.006 & $\begin{array}{l}\text { Alex. They be Gods of the } \\
\text { earth. Diog. Yea, Gods of } \\
\text { earth. (D1CLYLY) }\end{array}$ \\
\hline , & 24,184 & 24.57 & 14 & 5 & 0.001 & $\begin{array}{l}\text { hath not a Snaile, a Spider, } \\
\text { yea, a Neuft bin found there? } \\
\text { (D2CJONSO) }\end{array}$ \\
\hline
\end{tabular}

* Remember that the frequencies of yea are relatively low. This is also why there are only four collocate entries in Table 4; the collocate in fifth position failed to occur above the pre-defined minimum of ten.

Table 5. Collocates within a 5-word window to the right of yea in the CED Comedies

\begin{tabular}{|c|c|c|c|c|c|c|}
\hline Word & $\begin{array}{l}\text { Total no. } \\
\text { in CED } \\
\text { Comedies }\end{array}$ & $\begin{array}{l}\text { Expected } \\
\text { collocate } \\
\text { frequency }\end{array}$ & $\begin{array}{l}\text { Observed } \\
\text { collocate } \\
\text { frequency }\end{array}$ & $\begin{array}{l}\text { In } \\
\text { no. } \\
\text { of } \\
\text { texts }\end{array}$ & $\begin{array}{l}\text { Dice } \\
\text { coefficient } \\
\text { value }\end{array}$ & Brief examples \\
\hline but & 2,226 & 2.262 & 12 & 3 & 0.011 & $\begin{array}{l}\text { I did but iest, as I am a } \\
\text { Gentleman. Lem. Yea, but } \\
\text { there's a difference of iesting } \\
\text { (D1CCHAPM) }\end{array}$ \\
\hline , & 24,184 & 24.57 & 44 & 7 & 0.004 & $\begin{array}{l}\text { Shal. Sir, I thanke you: by yea, } \\
\text { and no I doe. (D2CSHAKE) }\end{array}$ \\
\hline$I$ & 8,016 & 8.144 & 14 & 4 & 0.004 & $\begin{array}{l}\text { Sen. Come not neare me sirra. } \\
\text { Men. Yea I will quarter him, } \\
\text { and }[\ldots] \text { (D1CWARNE) }\end{array}$ \\
\hline and & 6,074 & 6.171 & 10 & 5 & 0.003 & $\begin{array}{l}\text { And by this meanes we were } \\
\text { acquainted well: By yea and } \\
\text { nay, I will quoth I, and kist } \\
\text { her. (D2CHAYWO) }\end{array}$ \\
\hline . & 22,129 & 22.482 & 17 & 4 & 0.002 & $\begin{array}{l}\text { Del. Is this the best wine in } \\
\text { France? Sacr: Yea. } \\
\text { (DiCPEELE) }\end{array}$ \\
\hline
\end{tabular}


a rather more active role in marking major syntactic boundaries (see the brief discussion of the sentence in Culpeper and Kytö 2010, especially page 168 and the references mentioned therein). The other items in Table 5 differ from the collocates for yes. But appears in top position. It combines with yea to indicate agreement with an utterance but also a qualification. The presence of $I$ seems to suggest a characteristic function of yea, that is, affirmation followed by some kind of amplifying personal statement. Finally, and probably made it into the list of significant collocates because of its use in the expression "by yea and nay", but also because of its role as an amplifier, as in for example "but the linings be very foule and sweatie, yea and perhaps lowsie" (D1CCHAPM).

Tables 6 and 7 display the collocates for $A Y$.

Table 6. Collocates within a 5-word window to the left of $A Y$ in the CED Comedies

\begin{tabular}{|c|c|c|c|c|c|c|}
\hline Word & $\begin{array}{l}\text { Total no. } \\
\text { in CED } \\
\text { Comedies }\end{array}$ & $\begin{array}{l}\text { Expected } \\
\text { collocate } \\
\text { frequency }\end{array}$ & $\begin{array}{l}\text { Observed } \\
\text { collocate } \\
\text { frequency }\end{array}$ & $\begin{array}{l}\text { In } \\
\text { no. } \\
\text { of } \\
\text { texts }\end{array}$ & $\begin{array}{l}\text { Dice } \\
\text { coefficient } \\
\text { value }\end{array}$ & Brief examples \\
\hline Ay & 157 & 0.52 & 32 & 9 & 0.165 & $\begin{array}{l}\text { let his honour go which way it } \\
\text { will, dear Madam. Spar. Ay, } \\
\text { ay [...] (D }{ }_{3} \text { CWYCHE) }\end{array}$ \\
\hline$!$ & 1,484 & 4.912 & 23 & 8 & 0.027 & $\begin{array}{l}\text { Sir Cred. Cur'd! Prim. Ay, } \\
\text { there's a Doctor come to see } \\
\text { you (D5MILLE) }\end{array}$ \\
\hline . & 22,129 & 73.248 & 256 & 22 & 0.023 & $\begin{array}{l}\text { you know the Garret, Sir. } \\
\text { Franc. I, he knows it by a } \\
\text { good Token Husband. } \\
\text { (D3CDRYDE) }\end{array}$ \\
\hline$?$ & 3,071 & 10.165 & 33 & 15 & 0.02 & $\begin{array}{l}\text { shall I put up these together? } \\
\text { Bant. Ay, it is a pity to part } \\
\text { them (D5CFIELD) }\end{array}$ \\
\hline Sir & 1,892 & 6.263 & 15 & 7 & 0.014 & $\begin{array}{l}\text { You found the West Indies } \\
\text { very hot, Sir? Gib. Ay, Sir, too } \\
\text { hot for me. (D4CFARQU) }\end{array}$ \\
\hline
\end{tabular}

Regarding collocates to the left of AY, as displayed in Table 6, what is striking is their similarity to those of yes, displayed in Table 7. As with yes, a reduplicative form is in top position, and then we also see an exclamation mark, full-stop and question mark. Only the final collocate differs, though we should note that it has the lowest frequency of all. These results do not support Salmon's (1965:133) claim that $\mathrm{AY}$ falls in line with yea; instead, they suggest more of an affinity with yes. However, the collocates to the right of AY, as displayed in Table 7, do not entirely strengthen this affinity. Obviously, we find the counterpart of the reduplicative 
Table 7. Collocates within a 5-word window to the right of $A Y$ in the CED Comedies

\begin{tabular}{|c|c|c|c|c|c|c|}
\hline Word & $\begin{array}{l}\text { Total no. } \\
\text { in CED } \\
\text { Comedies }\end{array}$ & $\begin{array}{l}\text { Expected } \\
\text { collocate } \\
\text { frequency }\end{array}$ & $\begin{array}{l}\text { Observed } \\
\text { collocate } \\
\text { frequency }\end{array}$ & $\begin{array}{l}\text { In } \\
\text { no. } \\
\text { of } \\
\text { texts }\end{array}$ & $\begin{array}{l}\text { Dice } \\
\text { coefficient } \\
\text { value }\end{array}$ & Brief examples \\
\hline ay & 157 & 0.52 & 32 & 9 & 0.165 & $\begin{array}{l}\text { let his honour go which way it } \\
\text { will, dear Madam. Spar. Ay, ay } \\
{[\ldots] \text { (D }{ }_{3} \text { CWYCHE) }}\end{array}$ \\
\hline But & 2,226 & $7 \cdot 368$ & 28 & 12 & 0.023 & $\begin{array}{l}\text { Caesar, we are told, would } \\
\text { often faint. Bell. Ay. But } \\
\text { Caesar was a Lion when he } \\
\text { came to himself ((D4CKILLI) }\end{array}$ \\
\hline come & 798 & 2.641 & 10 & 5 & 0.02 & $\begin{array}{l}\text { every motion of thy Body } \\
\text { proclaims thee an Ass. Sir } \\
\text { Tim. Ay, Ay, come Madam, I } \\
\text { shall please you better when I } \\
\text { am Marry'd (D4CSHADW) }\end{array}$ \\
\hline$!$ & 1,484 & 4.912 & 16 & 5 & 0.019 & $\begin{array}{l}\text { Mrs. Clarinda said she was in } \\
\text { Boys Cloaths. Mr. Strict. Ay, } \\
\text { ay! I know it (D5CHOADL) }\end{array}$ \\
\hline , & 24,184 & 80.051 & 197 & 20 & 0.016 & $\begin{array}{l}\text { Went. Ha, ha, ha. Ilf. I, you } \\
\text { may laugh, but she shall cry as } \\
\text { well as I fort't, Bart. }\end{array}$ \\
\hline
\end{tabular}

form AY. We see a comma with an identical function to yes. There is an exclamation mark, a common feature of reduplicative affirmatives, including those involving yes (though not actually listed as a collocate of yes in Table 2, the exclamation mark did feature in a large number of the reduplicative examples). Where the collocates of AY depart from yes is with the appearance of but and come. But, it may be remembered, was recorded as a collocate to the right of yea. Come, although unique as a collocate of AY, is more in tune with the collocates of yea, which sometimes include a sense of qualification, than those of yes. Here, then, to the right of AY, there is some evidence for Salmon's (1965:133) claim that ay falls in line with yea. Overall, AY seems to be something of a mix between yes and yea in terms of collocates.

\subsubsection{Preceding questions}

In order to establish whether the Germanic question-affirmative pattern was alive and well during the period of the CED, I took 100 randomized instances of yes and the same for the $A Y$ group, and all sixty-two instances of yea. I then considered (a) how many were preceded by questions, and (b) how many were preceded by negative questions. The results are displayed in Table 8 . 
Table 8. Affirmatives after questions (figures are percentages with raw frequencies given in parentheses)

\begin{tabular}{lllc}
\hline & yes & yea & AY \\
\hline After questions (of any type) & $47(47)$ & $42(26)$ & $21(21)$ \\
After positive questions & $38(38)$ & $42(26)$ & $19(19)$ \\
After negative questions & $9(9)$ & $0(0)$ & $2(2)$ \\
After an utterance which is not a question & $53(53)$ & $58(36)$ & $79(79)$ \\
\hline
\end{tabular}

It is clear from the frequencies displayed in Table 8 that affirmatives quite often perform other functions aside from responding to questions; over half of all forms appear in contexts other than following questions. This is a particularly distinctive feature of the AY forms, 79 percent of which do not follow questions (compared with 58 percent for yea and 53 percent for yes). This result is consistent with what was found in the collocation analysis, where AY seemed to resemble yea in nonresponse functions. Here, it is clear that, whilst AY resembles yea in non-response functions, it is unlike yea in performing those functions more frequently. Note also that AY's pattern of usage would not support Blake's (2002:161) claim that AY encroaches on yes, possibly distorting its pattern of usage. AY appears after a question less than half as often as yes does (21 percent versus 47 percent), and these cases are quite evenly spread over the period.

Regarding negative questions preceding affirmatives, the frequencies are somewhat hampered by the fact that negative questions themselves are fairly rare. However, it is noteworthy that we never get yea after a negative question, but mostly yes and occasionally AY. This is consistent with the Germanic pattern, which would predict the use of yes, not yea after a negative question. In this respect, Salmon's (1965:133) claim that the Germanic pattern still existed, specifically in Shakespeare's time, is supported. There is no evidence for Crystal and Crystal's (2002:373) claim that the Germanic pattern breaks down around 1600, with yes taking over all functions. In the material of this study, whilst yes does appear after both positive and negative questions rather than just negative ones, yea never deviates from the Germanic pattern, always occurring after a positive question. However, it is in the period 1600 to 1639 that yes overtakes yea in terms of frequency (see Figure 1). By the period 1640 to 1679 , a mere nineteen instances of yea occur and none at all in later periods (see Figure 1). As yea disappeared from mainstream discourse, it seems that yes strengthened its role as an allpurpose affirmative response token, filling the space that yea after positive questions left behind. 


\section{Conclusions}

In the early modern period under scrutiny, 1560 to 1760 , yes was generally the dominant affirmative. However, in the first CED period, 1560 to 1599, yea was in ascendance. Thereafter, the relative frequency of yes rapidly increases until 1760, probably fuelled by the space left by the recessive yea, but possibly also by the fact that the CED text types are generally drifting towards a more conversational style. The collocates of yes confirm its status as a turn-initial response marker engaging the previous utterance, commonly a question. Yes has a loose relationship with the material that follows it. Sometimes it is combined with Sir or Madam, suggesting a polite routine associated with giving responses. Various "strengthening" devices are used in relation to yes. Yes can reduplicate, occur with exclamation marks or with a preceding $O$. Of all affirmatives, yes occurs most frequently after questions; however, even so, 53 percent of occurrences appear after utterances other than questions. Yes is also distinctive because it occurs most frequently, relative to the other affirmatives, after negative questions.

Yea collapses in frequency in the period 1560 to 1640 . It has a sprinkling of occurrences in all text-types, but it is particularly frequent in Handbooks, especially English language teaching handbooks. This seems to counter the idea that yea had been relegated to "regional dialect" (Crystal and Crystal 2002:373). I suggested that yea reflects the language of middle-ranking city dwellers, given both the kinds of middle-ranking characters in the ELT dialogues and the fact that the target audience for these handbooks was middle-ranking immigrants. Regarding collocates, yea overlaps to an extent with yes: for example, it typically occurs after a question mark or full-stop, reflecting its frequent turn-initial position as a response. But there are notable differences too, particularly regarding what occurs to the right of yea. But is the strongest collocate, indicating in combination with yea not only agreement with the previous utterance but also a qualification. Crystal and Crystal (2002:373) state that yea is "relegated to emphatic usage". However, there is no sense in which yea is "relegated" to emphatic functions, and in any case one could always point to the fact that this kind of function is even clearer in the case of yes, yet there is no claim that yes is thus relegated. Regarding its occurrence after questions, whilst yea is fairly similar to yes following positive questions, it is clearly distinguished from yes by the fact that it does not occur after negative questions.

The OED's argument that the development of affirmative Ay from the adverb $a y(e)$ (meaning 'ever or always') is blocked because it was never spelt $I$ is weak. The affirmative AY could be spelt the same way, ay(e) or $I$, from the beginning, and there is an entirely plausible path of pragmatic development connecting it to the adverb. AY increases in frequency during the seventeenth century, countering 
the OED's claim that AY was "exceedingly common around 160o". I suggested that the OED editors may have gained an erroneous impression of frequency in that period due to the salience of one of its variants, namely, I. AY does not completely fall into line with yea, as Salmon (1965:133) argues. Instead, the usage of AY increases in the seventeenth century, while yea decreases, reaching a plateau in the eighteenth century. This increase is consistent with Blake's (2002:161) claim that AY encroaches on yes, given that yes also increases. AY only appears in drama comedy with any frequency, and that might be evidence of a colloquial flavour. There, it occurs almost as frequently as yes, again something which is consistent with Blake's (2002:161) claim. No evidence for the OED's suggestion that AY may have developed as a dialectal form could be found. Regarding collocates, there are some distinct similarities with those of yes. Again this supports Blake (2002:161), but not Salmon (1965:133). However, right-hand collocates, lending a qualifying note, do suggest some similarities with yea. The differences from yes are apparent in its use after questions. AY appears less than half as often after questions compared with yes. It has mid-turn functions affirming and qualifying what has been said, but not necessarily what was said in the shape of a question from the previous speaker.

Regarding the Germanic pattern, Salmon (1965:133) is correct in saying that it can be detected in EModE. Contrary to Crystal and Crystal (2002:373), there is no evidence of a breakdown around 1600 , certainly not a complete breakdown. Whilst yes by this time was clearly no longer restricted to following negative questions, yea never changed its role as an affirmative after a positive question even after that date. Over the first three quarters of the seventeenth century, however, the use of yea declined, and yes expanded its role as an affirmative response after a positive question. So, it is around the middle of the seventeenth-century that we can say the Germanic pattern finally disappeared.

\section{Acknowledgements}

The research presented in this article was supported by the UK's Arts and Humanities Research Council (AHRC), grant reference AH/Noo2415/1. This publication is primarily based on datasets, listed immediately below, that are available for free.

\section{Corpora, dictionaries and tools}

A Corpus of English Dialogues 1560-1760 (CED). 2006. Compiled under the supervision of Merja Kytö (Uppsala University) and Jonathan Culpeper (Lancaster University).

CQPweb. Created by Andrew Hardie (Lancaster University). See: https://cqpweb.lancs.ac.uk/. Early English Books Online: Text Creation Partnership (EEBO-TCP). Phase II release, accessed via CQPweb. 
OED (Oxford English Dictionary) Online. June 2017. Oxford University Press. See: http://www.OED.com

\section{References}

Archer, Dawn. 2005. Questions and Answers in the English Courtroom (1640-1760): A

Sociopragmatic Analysis. Amsterdam: John Benjamins Publishing. https://doi.org/10.1075/pbns.135

Biber, Douglas, Stig Johansson, Geoffrey N. Leech, Susan Conrad and Edward Finegan. 1999. Longman Grammar of Spoken and Written English. New York: Longman.

Blake, Norman. 2002. A Grammar of Shakespeare's Language. Basingstoke: Palgrave. https://doi.org/10.1007/978-1-4039-1915-1

Blayney, Peter W. 1991. The First Folio of Shakespeare: In Conjunction with the Exhibition at the Folger Shakespeare Library, Washington, DC April 1, 1991-September 21, 1991. Washington, District of Columbia: Folger Shakespeare Library.

Crystal, David and Ben Crystal. 2002. Shakespeare's Words: A Glossary and Language Companion. London: Penguin.

Culpeper, Jonathan and Merja Kytö. 200o. "Data in Historical Pragmatics: Spoken Interaction (re)Cast as Writing". Journal of Historical Pragmatics 1 (2): 175-199. https://doi.org/10.1075/jhp.1.2.03cul

Culpeper, Jonathan and Merja Kytö. 2010. Early Modern English Dialogues: Spoken Interaction as Writing. Cambridge: Cambridge University Press.

Filppula, Markku. 1999. The Grammar of Irish English: Language in Hibernian Style. London: Routledge.

Filppula, Markku and Juhani Klemola (eds). 2009. "Re-evaluating the Celtic Hypothesis". (Special issue.) English Language and Linguistics 2: 283-330.

van Gelderen, Elly. 2013. "Null Subjects in Old English”. Linguistic Inquiry 44 (2): 271-85. https://doi.org/10.1162/LING_a_00127

Hickey, Raymond. 2012. "Early English and the Celtic Hypothesis". In Terttu Nevalainen and Elizabeth Closs Traugott (eds), The Oxford Handbook of the History of English, 496-507. Oxford and New York: Oxford University Press.

Hoffmann, Sebastian. 2004. "Using the OED Quotations Database as a Corpus - a Linguistic Appraisal". ICAME Journal 28: 17-30.

Rusten, Kristian A. 2013. "Empty Referential Subjects in Old English Prose: A Quantitative Analysis”. English Studies 94 (8): 970-992. https://doi.org/10.1080/0013838X.2013.839140

Salmon, Vivian. 1965. “Sentence Structures in Colloquial Shakespearian English”. Transactions of the Philological Society 64 (1): 105-40. https://doi.org/10.1111/j.1467-968X.1965.tboo321.x

Vennemann, Theo. 2009. "Celtic Influence in English? Yes and No". English Language and Linguistics 13: 309-334. https://doi.org/10.1017/S1360674309003049

Walkden, George. 2013. "Null Subjects in Old English". Language Variation and Change 25: 155-178. https://doi.org/10.1017/So954394513000070

Wallage, Phillip and Wim Van der Wurff. 2013. "On Saying 'yes' in Early Anglo-Saxon England”. Anglo-Saxon England 42: 183-215. https://doi.org/10.1017/S0263675113000100

Wikberg, Kay. 1975. Yes-No Questions and Answers in Shakespeare's Plays: A Study in Text Linguistics. Åbo: Åbo Akademi. 


\section{Address for correspondence}

Jonathan Culpeper

Department of Linguistics and English Language

Lancaster University

County South

Lancaster, LA1 $4 \mathrm{YL}$

United Kingdom

j.culpeper@lancaster.ac.uk 